\title{
Salafism in Tunisia: Challenges and OPPORTUNITIES FOR DEMOCRATIZATION
}

\author{
Stefano M. Torelli, Fabio Merone and Francesco Cavatorta
}

\begin{abstract}
Mr. Torelli is PhD candidate at the University of Rome "La Sapienza" and a founding member of the Italian Centre for the Study of Political Islam (CISIP). Mr. Merone is research associate with the Germany-based Gerda Henkel Foundation. Dr. Cavatorta is senior lecturer at the School of Law and Government, Dublin City University. ${ }^{*}$
\end{abstract}

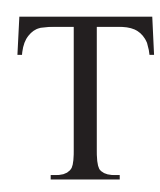

he first successful free and fair elections, held in October 2011, for the Constituent Assembly and the formation soon after of a three-party ruling coalition ${ }^{1}$ seem to have set Tunisia squarely on the path towards democratization. Since then, very little attention has been paid to the country that kicked off the Arab Spring. Tunisian events have faded into the background of current affairs for two reasons. First, the focus has shifted to the fate of countries with greater geostrategic importance, such as Egypt, and with the potential of setting off a regional conflagration, such as Syria. Second, according to some scholars, ${ }^{2}$ Tunisia has already succeeded in its transition to democracy, although it has yet to consolidate its new institutions; therefore, not much can go wrong at this stage. Both reasons are valid to the extent that Tunisia is not a prominent regional actor and that its transition has indeed been smoother than those in Egypt, Yemen and Libya, where political volatility is higher. Thus, the media spotlight has moved to other countries. The little attention that Tunisia has received more recently has focused overwhelmingly on the emergence of the bogeyman of salafism.

Far from ushering in the triumph of liberal and secular democratic forces across the region, the Arab uprisings have led to the electoral success of Islamist parties and movements. ${ }^{3}$ This is no longer as problematic as it was in the late $1980 \mathrm{~s}$ and early 1990s, when, for example, the Islamist party Front Islamique de Salut (FIS) was poised to take power in Algeria. Islamist movements have gone through a process of political moderation; many of them embrace the mechanisms of democracy and support basic human rights. ${ }^{4}$ However, the rise of Islamism in the wake of the Arab uprisings is not limited to what can be labeled mainstream Islamist par-

\footnotetext{
* Fabio Merone and Francesco Cavatorta are grateful to the Gerda Henkel Foundation for funding this research in the context of the program "From Over-Estimation to Under-Estimation: The Trajectory of Political Islam in Five MENA Countries."
} 
ties deriving inspiration from the Muslim Brotherhood. Salafism, in its different strands, has surfaced as a potent political and social force, capturing a significant degree of attention and generating profound fear. In the capital and other cities around Tunisia, public rallies by thousands of salafist activists and supporters have occurred over the past 18 months and still take place today, raising fears that they might be the ultimate beneficiaries of the fall of Ben Ali and the inability of the current government coalition to solve the country's problems.

The rise of salafism in Tunisia has been both surprising and problematic. Unlike in Egypt or Yemen, there was very little evidence that such a phenomenon even existed in Tunisia. Policy analysts, secular politicians and civil-society activists still claim today that it is an imported phenomenon, completely extraneous to Tunisian political, intellectual and social history. It is also problematic because its public presence in a democratizing environment can, according to some, negatively affect the way in which Tunisia will build its new political system and deal with the question of its identity and core values. ${ }^{5}$ Surprise and wariness characterize as well the reaction of the international community, whose attitude towards salafism is extremely negative. It is perceived to pose a danger to liberal democracy and the stability of the international system.

While not underestimating the phenomenon, this examination of Tunisian salafism challenges the widely held assumption about its foreign origin, highlights its internal divisions, and provides a more nuanced analysis of the complex relationship of its different strands with nascent democratic institutions. Scholarly research on Tunisian salafism requires time. It is a continuously developing political phenomenon, but nuanced analyses are necessary in order to counter the more alarmist journalistic narratives. The objective is not to minimize the salafist presence on the public scene or condone the policies salafists want to see implemented, but simply to offer a more balanced examination of its place in the evolving Tunisian society.

An unprecedented level of openness has characterized the new Tunisian political context after Ben Ali's fall, favoring the emergence of many new political and social actors. Despite their absence from the anti-regime protests, Islamist movements have been able to take the greatest advantage of this situation. The previously outlawed Ennahda party led by Rachid Ghannouchi did extremely well in the October 2011 elections, winning 89 of 217 seats in the Assembly and leading a threeparty coalition. Through its decision to play the democratic game and demonstrate a significant degree of political pragmatism, Ennahda has become a key actor in the current process of democratization. It even seemed for a time to monopolize the representation of political religiosity. However, the emergence of salafi actors offering a much more radically conservative interpretation of Islam in politics and social life has challenged such a monopoly, shocking both Tunisian society and foreign observers.

There is no doubt that many of the salafists' views on how the institutions of the state should look and what kind of social, economic and foreign policies Tunisia should implement are both illiberal and largely unappealing, as it stands, to the majority of Tunisians, who feel that all of this is a Wahhabi deviation coming from Saudi Arabia. However, denying salafism its 
domestic roots, as if the phenomenon were simply an aberration in Tunisian society and a mortal threat to the nascent democratic political system, does not permit one to understand its growth, its internal differences and how it relates to the other Tunisian social and political actors.

\section{INDIGENOUS OR IMPORTED?}

Far from being a recent foreign import, Tunisian salafism, in both its scientific and Jihadi versions, has its roots in the dissatisfaction of some Islamists with the political thinking and strategies of its 1980s predecessor, Ennahda or the Mouvement de la Tendence Islamique (MTI), which had accepted the principle of democratic procedures to govern society. Thus, a number of militants left the Islamist movement before it became a party in order to create the Tunisian Islamic Front (TIF) in 1986, although the creation of the TIF remained known only to its leaders until the security services discovered the founding documents in 1990 and began a very harsh repressive campaign against it. Mohammad Ali Hurath, Abdallah al Haji, Mohammad Khoujia and Mongi al-Hachmi were its founding members. This group had a very limited influence, due to the repressive policies of the government.

A number of TIF militants left Tunisia for Pakistan or Bosnia, where they took part in the Afghani and Bosnian jihads; others went into exile and others still remained in Tunisia, either in jail or marginalized in society. After the fall of the regime, a number of former members returned to Tunis with the intention to establish a political party that would run in the 2011 elections. At the same time, it became evident that a number of salafist militants had been freed from Tunisian jails and were ready to return to the public scene. ${ }^{6}$
The permit to set up a party did not arrive in 2011, in time for the October elections, because the transitional authorities did not trust the democratic commitment of any form of salafism. However, Jabhat al-Islah (Front of Reform) was eventually legalized on March 29, 2012, possibly because Ennahda, now in power and keen to bring salafists into the political system, vouched for it and for its commitment to democratic procedures. In May of the same year, the party was formally presented to the public. In attendance were a number of prominent religious figures and, crucially, Rachid Ghannouchi, president of Ennahda. The president of the first legal salafist party in Tunisia is Mohamed Khouja, who had been a prominent member of the TIF in the 1980s. According to Rafik Aouni, leading member of the party, Jebhat al-Islah has been set up by those salafists "who had remained in Tunisia throughout the Ben Ali era, although contacts and channels of communication are still open with the ones who left; and in case they came back to Tunisia they would naturally join the party."

The repressive measures that Ben Ali enacted following his accession to power targeted first and foremost the Islamists, whether salafists or others; and their disappearance from the public and political scene was often applauded in Western circles. The authoritarian stability of the Ben Ali regime, however, did not go unchallenged. Despite receiving very little attention in both academic and policymaking circles, spaces of resistance and dissent sprang up, particularly during the 2000s. ${ }^{8}$ Among these dissidents, we also have a small cohort of young men who embraced salafism in order to satisfy their spiritual needs, find a political framework through which they could express their 
resentment of an authoritarian and corrupt regime, and demonstrate solidarity with the great pan-Arab causes of the decade: Palestine and Iraq.

The impulse for the resurgence of indigenous salafism, however limited, came through "contamination" by Tunisians who had engaged in foreign jihads of young men who had not gone abroad but embraced what salafism stood for. The Palestinian Intifada, the war in Iraq, and the experience gathered in

Tunisia was a deeply authoritarian state with a predatory economy favoring politically connected elites while the wider population, particularly in working-class and disadvantaged rural regions, suffered from rapidly declining living standards. and recruiting; its external image did not wholly correspond to reality. Rather than a country where democracy was being progressively installed, human rights increasingly respected and a market economy delivering high standards of living, Tunisia was a deeply authoritarian state with a predatory economy favoring politically connected elites while the wider the European networks — both logistical and theoretical - have been formative for the younger generation of Tunisian salafists, especially the jihadists. Since the mid-2000s, Tunisians who had fought in Afghanistan, Bosnia, Chechnya and Iraq have linked up with outside jihadists to strengthen a presence in Tunisia, where young men had begun to practice salafism in order to combat the secular regime of Ben Ali.

The architect of this attempt was Lassaad Sessi. In April 2006, Sessi and a small group of armed Jihadists crossed the border from Algeria into Tunisia and participated in a gunfight with Tunisian security forces. Having escaped the security forces, Sessi managed to recruit a few young militants in Sousse, Tunis and Sidi Bouzid. What is surprising is that a recruiting campaign could occur despite the supposed insularity of Tunisia from extremism and the omnipresence of its security apparatus.

In 2006, Tunisia was already a rather fertile terrain for salafist propaganda ing standards. ${ }^{9}$ In this context, the jihadist group Jund Assad ibn el-Furat was set up in 2006, although severely repressed soon afterward. According to Nadhif,
All the young people recruited into Jund Assad ibn Furat came under the control of the security services because of their assiduous frequenta- tion of mosques and because of their physical appearance and attire. They were continuously brought to police stations for questioning and then released. They were suspects, always under pressure and socially margin- alised in the sense that police attention meant unemployment."10

This continued pressure ensured deeper involvement with the jihadi salafist movement; greater repression turned into greater commitment to the cause. It is these young men, numbering a few thousand - together with even more radical jihadi salafists who had actually taken up arms against Ben Ali in the mid-to-late 2000s - who were freed from Tunisian 
jails in the immediate aftermath of the revolution and became the catalysts for increased salafist recruiting and activism. The vast majority of them ended up in the broader salafist tendency, with a significant number joining Ansar al-Sharia, which was set up in April 2011 under the leadership of Abu Ayyad al-Tunisi, whose real name is Sayf Allah Umar bin Hussein. Abu Ayyad, with Tarek al-Maaroufi, had founded a Tunisian group of jihadis in Afghanistan in 2000. After having attempted terrorism in Europe, most of them were arrested. Abu Ayyad was captured in Turkey and deported to Tunisia on charges of international terrorism in 2003. ${ }^{11}$ Tarek al-Maaroufi returned to Tunis after the revolution but distanced himself from jihadi activism.

Abu Ayyad, in prison in Tunisia, fraternized with the young local men who were the targets of Ben Ali's repression for their radical Islamist views. It is the linkage between international jihadism and local religious radicalism that shapes Tunisian salafism. The international factor is certainly important and to an extent superficially justifies those who see Tunisian salafism as an import. However, it should be highlighted that the ones who are involved, whether returning exiles or local activists, are all Tunisians reacting to Tunisian conditions. This includes the international jihadis who had left because of repression from the Ben Ali regime, which had never permitted any sort of Islamist politics. Ansar al-Sharia represents today the most important organized salafist-jihadi group in the country.

Thus, while there are certainly links with events and groups outside of Tunisia, the salafist phenomenon cannot be labeled as "foreign." It has characterized, although very marginally, Tunisian society since the beginning of the 1980s at least.

\section{INSTITUTIONS V. STREET POLITICS}

The definition of salafism is still a subject of debate among scholars. If we follow the classical interpretation in the modern era, it dates back to the late nineteenth century, with the emergence in the Islamic world of Islamic Reformism (islah). The term salafism derives from the Arabic salafiyyun, "the ancestors," the first three generations of Muslims, deemed to be the most pious believers. Salafiyya theorized a return to original Islam through the elimination of those elements that, throughout history, have been introduced from the outside and inevitably changed the essence of its origins. The use of the term salafism in reference to current Islamic radical movements is relatively new and has partially lost the meaning it had initially assumed during the era of Islamic reformism. Referring today to organizations and groups characterized by a purist interpretation of Islam as salafism is a kind of after-the-fact definition of a term that originally had a specific meaning.

Such a theoretical premise is fundamental to any discussion of salafism today, regardless of the context. Wiktorowicz identifies three forms of salafism: purist, political and jihadist. ${ }^{12}$ Purist salafists are primarily focused on maintaining the purity of Islam, in compliance with the requirements of the Quran and the Sunna and with what was predetermined by the consensus (ijma) of the companions (ansar) of Muhammad. The strategy of action favored by purist salafism is based on two main pillars: propaganda (dawa) and education (tarbiyya). These tools are preferred to political activism, as purists assume Islamization from below and do not interfere with the legal and institutional frameworks in which governments operate. This is justified by pragmatic opportunism. They 
fear that if any political action, particularly violence, threatens the very existence of the state, repression will ensue.

In this perspective, political movements and jihadists are criticized because their actions are counterproductive and actually lead to the repression of Islamist activism. The strategy that purist salafism follows results in a kind of isolationism or retreat from political and social institutions.

This finds its source of legitimacy in the first phase of Muhammad's preaching (the so-called Meccan period), when the hostile environment urged the Prophet to prefer forms of "horizontal" propaganda rather than political action. On the contrary, the choice of political activism is the one political salafism adopts in response to the frustration over purists' persistence in remaining outside the political arena. Therefore, political salafism acts directly within the political system to influence its choices. Its strategy is motivated by the need to deal directly with current affairs; and it accuses purist isolationism of misinterpreting the current reality, making Islam irrelevant for Muslims.

Finally, jihadist salafism is a form of violent opposition to "unjust rule," aimed at establishing an Islamic state. Unlike political salafism, whose formation took place in Islamic universities based on the classic texts of salafism, "[...] jihadists have received their political training on the battlefields." ${ }^{13}$ The example of the armed struggle against the Soviet invasion of Afghanistan in the 1980s represents the model to follow in pursuit of their goals. Amghar, ${ }^{14}$ Hegghammer, Zelin ${ }^{15}$ and Bonnefoy ${ }^{16}$ are other scholars who have attempted to classify salafism through similar categories, at times expanding on them to refine the categorization. Their work should be commended for setting out quite clearly the differences that exist within the salafist camp. These categorizations are helpful in the Tunisian case; there are profound divisions and distinctions among the different salafist groups active in the country. Of particular interest is the relationship such groups have with the nascent democratic institutions and the other political and social actors that have bought into and support the construction of a democratic Tunisia, including Ennahda.

Understanding such relationships is vital for three reasons. First, sectors of salafism can gradually be brought around to accept the mechanisms of democracy and the legitimacy of the state's institutions, going through a process of moderation similar to the one that Ennahda, for instance, has experienced. This process of institutionalization could paradoxically strengthen the democratic process in so far as the inclusion of salafists in the political system could indicate that there is "room for everyone" at the table, as long as some key principles of democracy are respected. Giving legal and institutional voice to the small sectors of the population buying into the salafist political project would symbolize the success of Tunisian democracy.

Second, the absence of economic 
growth, the continuation of profound inequities, and the perceived increasing distance between ordinary citizens and the new political system, combined with the inability of the state to cope with the avalanche of socioeconomic demands from civil society, would certainly embolden those salafist activists who reject the democratic game, favor street politics and are ultimately anti-government. In such a scenario, the rather large Islamist vote that is today largely channeled to Ennahda could begin to question the pace of the reform process and embrace more radical forms of political engagement, including the use of violence. Criticism of Ennahda is emerging, even from the party's youth wing, which recently criticized the leadership for its hesitancy in tackling economic and social problems.

Finally, accounting for salafist activism in all of its forms is an essential part of the story of anti-Islamist mobilization in Tunisia, in so far as the fear factor is stimulating the secularists into embracing the newfound freedoms and using them to advance their own agenda. ${ }^{17}$ This is particularly important. The mobilization of leftists and liberals can ensure that political representation is given to all sectors of Tunisian society. Apathy would benefit Islamism, which has traditionally been better at turning people out, both at the polls and in the streets. The regressive social measures that salafism stands for in the eyes of secular Tunisians paradoxically ensure that there will be no complacency, further strengthening democratic politics.

\section{INSTITUTIONALIZED SALAFISM}

As mentioned earlier, the older generation of salafists embodied by people like Mohammed Khouja, one of the founding members of TIF in the late 1980s, intended to set up a salafist political party immediately after the revolution. Converted to institutional politics after having been involved in jihadi salafism, Khouja represents an older generation that advocates the Islamization of the state through the "reformist salafism method." ${ }^{18}$ In short, they do institutional politics. This current is more pragmatic and realistic than the jihadists and is uncomfortable with the idea of retreating into isolationism. Thus, one of the strategies of action of reformist salafism is to participate actively in the political and institutional processes of the state, even under conditions in which sharia is not applied. In fact, they consider the choice of participation as the most rational approach to changing society and achieving the application of sharia, ${ }^{19}$ but the means are in accordance with democratic mechanisms.

Khouja and other former members of TIF reunited with the clear intention of establishing a political party, and in March 2012 the national authorities finally legalized Jabhat al-Islah, the first official salafi party in Tunisia. The party's name, linked to reformism, and its request to participate in the 2013 elections are two elements that help to better locate the Front squarely within the scientific reformist salafi camp. Given its willingness to participate in the political process, Jabhat al-Islah has disclosed its own political program identifying the general objectives of the party, as well as specific proposals for the political, economic, social and cultural fields. ${ }^{20}$

The general objectives of the party are the creation of an Islamic state and the application of Islamic law in all spheres of life. Although there are references to respect for pluralism and for the principle of alternance (the alternating of power), it specifies that political life should be conducted 
within the limits imposed by sharia. This suggests that Islam has pre-eminence in the political project of the party at the expense of the pluralism that liberalism advances. In some ways, the Front is an anti-system party. It does not buy into the idea that all voices are legitimate and that the state should protect them. In fact, the state should enforce only what religion has determined to be right. For instance, at the first party congress, held on July 8, 2012, GeneralSecretary Muhammad Khouja reaffirmed that sharia is the only way to rule. ${ }^{21}$

In economics, it proposes to ban interest rates and to restore the waqf system, giving prominence to an "Islamic welfare state." In the cultural are quite widely shared across the political spectrum. Palestinian Hamas leaders Ismail Haniyeh and Khaled Mishal were received by politicians from all political parties and all ideological persuasions when they visited Tunis. Violence to achieve political objectives is explicitly rejected. It is specified in its manifesto that the methods through which political affairs should be conducted are demonstrations, sit-ins, participation in elections and propaganda through traditional media.

In addition to the Front of Reform, another party that professes itself to be salafist and has the ultimate goal of establishing Islamic rule is al-Rahma (Mercy), which was legalized on section of its manifesto, the party emphasizes the importance of ijtihad (argumentation) as a means to reform Islam and recognizes Western innovations in technology and science. In terms of social policies, the party criticized the choice not to include a reference to Islamic law in the new constitution and called for the re-introduction of polygamy and the abolition of the egalitarian Code of Personal Status, adopted by Bourguiba in $1956 .{ }^{22}$ This last point is particularly controversial. It would question the social advances of Tunisian women and impose the regressive views that secular civil society and political parties have strongly mobilized against.

In foreign policy, the Front reaffirms the rejection of any normalization with Israel and makes explicit reference to the Palestinian cause. However, these are not particularly contentious issues; they

July 31,2012 . The party is led by Sayd al-Jaziri, a salafi preacher who has lived in Canada. After being sentenced in absentia under the Ben Ali regime for his membership in Ennahda, al-Jaziri was no longer able to return to Tunisia until the fall of the regime. During his years in Canada, he repeatedly argued for the need to adopt sharia and distinguished himself as one of the spiritual leaders of the Islamic community. There is a third salafist party, al-Asala (Authenticity), led by Mouldi Mujahid and tied to the eponymous party in Egypt.

These parties do not enjoy much popularity, but what is more important is the signal that they send in accepting the institutional parameters. In particular, the ruling Ennahda party has been working towards the inclusion of salafists into the political game since they emerged on the scene because Ennahda itself has salafist 
roots. Before its reintegration into Tunisian political life, Ennahda could have been categorized for a time as a salafist movement, as its rhetoric and social and political activities reflect the desire to return to the original form of Islam. However, it should be emphasized that from the outset, Ghannouchi kept referring to the compatibility between democracy and Islam, indicating a degree of ideological flexibility that current salafists do not yet possess. ${ }^{23}$ Ennahda was a salafi movement; it stood in direct continuity with Islamic reformers, standing between a purist salafism and a more political one, which determined whether it could operate in the Tunisian context. Ghannouchi defines himself a salafi, but only "to the extent that salafism is understood as a return to the noble values of Islam based on Quran and Sunna." ${ }^{24}$

Nevertheless, the ongoing transformation of his party makes Ennahda an expression of political Islam that has distanced itself markedly from the current salafi galaxy. It has been able to integrate itself into the institutional system, especially because it has given up the objective of creating an Islamic state and applying sharia. The attempt to integrate current salafists is an important objective of Ennahda for a number of reasons. First, there is a degree of understanding of the radical positions of the salafists. Many Ennahda members used to hold similar views in the past and have come around to different methods and policies only rather recently. Second, the inclusion of salafists in the political game might benefit Ennahda electorally, given that the radicalism of salafists would be neutered; having joined the political system, salafists would no longer seem so radical. Finally, Ennahda can use salafists to provide a more moderate image of itself, arguing that it is defending democracy and human rights by acting as a rampart against salafism.

The problem with salafists who have joined the institutional game is that they tend to represent an older generation with little following. Therefore, a much younger and larger cohort of salafists, who grew up in the radicalized environment of the 2000s, remains outside institutional politics and prefers to rely on bottom-up activism and street politics. It is these movements that present a real challenge to the nascent political order and to Ennahda, as does Hizbu-t-Tahrir, a transnational Islamist movement with a very distinct ideological and political agenda that attempts to go beyond the perceived ideological duopoly of the Muslim Brotherhood's Islamism and salafism. ${ }^{25}$

\section{ANSAR AL-SHARIA}

Ansar al-Sharia was set up in April 2011 under the leadership of Abu Ayyad al-Tunisi, a jihadist who fought in Afghanistan during the battle of Tora Bora and in 2003 was deported to Tunisia on charges of international terrorism. ${ }^{26}$ Once freed, in the aftermath of the revolution, Abu Ayyad began organizing salafist activism, thanks to the contacts and prestige that prison gave him. In addition, the group can count on a prominent spiritual leader, Shaykh Khatib al-Idrissi, who had condoned the use of violence against the Ben Ali regime, was in prison for two years and enjoys significant credibility. A year after its creation, the movement seems to be growing, as demonstrated by the mass rally in Qayrawan to celebrate its first anniversary, attended by thousands of people.

Despite a leadership profile that suggests that Ansar al-Sharia is a revolutionary or jihadist movement, armed violence against the post-Ben Ali order has not oc- 
curred. The movement prefers to conduct what can be termed street politics in order to achieve its political and social objectives inside Tunisia. This choice is not only ideological, but also pragmatic. Ansar al-Sharia has a loose official structure, with Abu Ayyad at the top as the charismatic leader, Sami Assyd charged with organizational matters and logistics, and Hassen Ben Brik as dawa officer. ${ }^{27}$ It follows that at the moment Ansar al-Sharia functions more as a label that many different local groups operating across the country have chosen. In this context, the role of local sheikhs, usually charismatic figures with great preaching skills, is fundamental to the success of the group.

In any case, it is groups referring broadly to Ansar al-Sharia that openly challenge the democratic direction of the country. Ideologically, they reject democracy as extraneous to the teaching and the "living" of Islam and therefore concentrate their effort on the dawa, attempting to exercise control over society and the behavior of individuals in order to reinforce social mores, the "straight path" of Islam in its strictest interpretation. First, the group organized "occupy mosques" campaigns to chase out imams who were accused of having been too loyal to the regime. Second, it called attention to the plight of Tunisian prisoners in Iraqi jails. The group organized advocacy campaigns and lobbied the government to intervene on their behalf. Family members of the prisoners set up an association to highlight the issue. Finally, it organized campaigns to defend religious symbols, to make blasphemy a criminal offense, to introduce gender segregation in public spaces, and to encourage charitable activities. Sheikh Khatib Idriss argues as follows:
Those who eliminate jihad from the tools with which the message of Islam should be propagated are not salafist because they eliminate a pillar of Islam,... and as Muslims we have to accept Islam in its entirety.... The Jihadi salafist is different from other Muslims because he is coherent with the whole of the revelation and refuses to dilute it in order to become a moderate simply to appease the government or the unbelievers....Our instrument is preaching... the spreading and teaching of Islam in a peaceful manner. We do not wish to make war on anybody because the term jihad does not exclusively mean fighting, but it is also the struggle to propagate the message of Islam through the dawa, through participation in the solution of problems, although in the confines of sharia law. ${ }^{28}$

Calling for jihad in the form of fighting is not yet an option for the current generation of salafists outside of institutional politics. It is well known that the group considers the current government to be hostile to salafism, but the government cannot be considered an enemy to be fought through an armed struggle. It has yet to prevent the teaching and the dawa of the salafist groups. Within Tunisia, the movement considers society its privileged field of action; its purpose is to Islamize the country through social activism. In this context, the continuing commitment of Ansar al-Sharia to the delivery of social services is paradigmatic. Distributing essential goods and food to the rural poor or bringing aid to people affected by a wave of bad weather in January-February 2012 are only two examples of what the group does. On the occasion of the storms in the northwest of the country, Ansar al-Sharia organized aid caravans in the regions of 
Janduba and Kasserine, more specifically in the city of Haydrah. ${ }^{29}$ This activity falls within the realm of dawa and is in direct contrast to the government's poor efforts. The movement therefore attempts to replace state actors, demonstrating its ability to generate support for its activities and, at the same time, to highlight the state's deficiencies.

Moreover, the commitment to social assistance is not limited to such one-off catastrophes. The distribution of food and essential goods extends to the entire national territory and is targeted at poor families in remote areas of the country, as well as in the suburbs of the capital. On the Ansar al-Sharia Facebook page, one of the group's most important propaganda tools, there are dozens of photographs and press releases highlighting this kind of social commitment. ${ }^{30}$ Unlike in other countries of the region, Tunisian Islamist movements have never before been able to operate in the social context and are therefore using this newfound freedom to invest resources there. This possibility for social action partly explains why a leadership formed through violent jihadism has decided not to use violence against a regime they consider insufficiently Islamic - and therefore unjust. Using violence might cause the movement to be repressed or banned.

The hope of Ansar al-Sharia is that the shortcomings of the new political system will be such that ordinary Tunisians will fall increasingly into the salafist ranks and support a much more radical political project. For its part, the government and Ennahda, in particular, are keen to avoid an open confrontation with Ansar al-Sharia, although the attack on the U.S. embassy in September 2012 severely tested the ruling majority's tolerance. Ennahda, in particular, does not want to ban the move- ment; they argue that this would simply drive them underground and turn them into victims. But further high-profile incidents undermining the image of Tunisia abroad might force the party's hand. Thus, despite a number of episodes bordering on rioting that occurred over the past few months, the group remains broadly nonviolent, although anti-government. ${ }^{31}$

The jihadi origin and nature of the group is demonstrated on the international stage, as it openly embraces jihadism and violent struggle. Abu Ayyad himself stated that one of the ultimate goals of the movement is to wage jihad abroad, Tunisia being only a "land of prayer." Through several press releases issued by al-Qayrawan Media Foundation's blog, Abu Ayyad praised Osama bin Laden at the time of his death, calling him a shahid and referring to the former head of al-Qaeda as "our leader." ${ }^{32}$ More than once the leader of Ansar al-Sharia has justified the actions of global jihadists abroad, and specific episodes show its proximity to jihad beyond Tunisian borders. In November 2011, for example, the movement's Facebook profile posted photos of the body of Tunisian jihadist Yosri al-Triqi, sentenced to death in Iraq for attacks against a Shiite mosque in 2006. He was also glorified in a post entitled "Farewell to our martyred brothers." ${ }^{33}$ In May 2012, dozens of militants occupied the waiting room of the international airport of Tunis-Carthage to protest the authorities' decision to deny entry to the country to Umar al-Hadushi, a member of the Moroccan jihadist group linked to the 2003 Casablanca bombing. ${ }^{34}$

Finally, jihadists from Tunisia were arrested in Syria, which has become one of the causes of global jihadism. According to some Tunisian sources, salafi-controlled mosques in Tunisia engage in propaganda 
activities aimed at sending jihadists to Syria to fight the regime. ${ }^{35}$ Ansar al-Sharia has repeatedly fomented efforts against the regime, including hosting on its Facebook page several posts from the Syrian jihadist group Jabhat al-Nusra li-Ahlal-Sham (Front of the Victory for the People of Greater Syria), an organization that has claimed responsibility for most of the 2012 terrorist attacks in Damascus and Aleppo. It appears that Ansar al-Sharia, when referring to issues outside of Tunisia, acquires an attitude of revolutionary salafism, sympathizing with the cause of global jihad.

In the current scenario, the dual nature of Ansar al-Sharia provides an emerging alternative to Ennahda, with which it competes for support in the country. Ghannouchi's party is, in fact, accused of having joined the institutional system and betraying the cause of Islamization, as its refusal to introduce references to sharia in the new constitution amply demonstrates, according to salafists. Finally, it should be underlined that, although Ansar al-Sharia is the most influential and visible anti-government force, there are other movements that intend to establish an Islamic state but have not formed political parties. There is, for instance, al-Jamiyya al-Wasatiyya li-1-Tawiyyawa-1-Islah (Centrist Association for Awareness and Reform), created in November 2011. The association does not participate in political life in Tunisia, but it is interested in having a role in public life, devoting itself to tarbiyya. Adel al-Almi, its leader and founder, planned to create a real religious police force, to be deployed in the streets in order to enforce Islamic law. The basic aim of the association is to enforce sharia on the basis that Tunisia is a Muslim country. ${ }^{36}$

The movement's strategy also involves influencing the legislative process in order to provide the legal system with juridical rules that can serve as tools for the application of Islamic law. However, during the month of Ramadan in 2012, al-Almi was accused of inciting violence, inviting those who do not practice ritual fasting not to appear in public, in order "not to provoke the ire of salafists," and declaring that bars and restaurants should not serve food or drink during fasting hours. ${ }^{37}$ At a meeting in Tunis on sharia in March 2012, the association's leader declared that he "would fight against everything that is against sharia." 38 Unlike Ansar al-Sharia, the Centrist Association for Awareness and Reform operates exclusively in the Tunisian context. What the two movements have in common is their unwillingness to participate directly in the political process, their shared emphasis on the dawa aimed at creating an Islamic state, and their preferred method of action: demonstrations.

\section{CONCLUSION}

A number of important points emerge from the analysis of Tunisian salafism that are crucial to future political developments in the country. First, it should be underscored that Tunisian salafism is not a foreign import, but represents the political demands of a sector of the population that has found in the liberal post-Ben Ali atmosphere an opportunity to organize openly and proselytize for a social project that stands in sharp contrast to the direction taken so far. Salafists are very much the product of Ben Ali's authoritarian, secular and mafia-style political economy. Its legacy is an impoverished country in which a part of the population, however small, has been radicalized to the extent of embracing salafism. Although the views and policies that Tunisian salafism stands for are not appealing to the majority of 
the population, their right to express them has to be protected. This leads to a second challenge: the internal divisions that operating in a liberal environment has created.

While an older generation of salafists has come back to the country to set up political parties that accept democratic mechanisms that did not originate in Islamic law, a younger cohort has chosen to remain outside the political system, operating through preaching and social activism and maintaining links with the global jihadi movement. This suggests that the varied nature of Tunisian salafism is an indicator of how it is going to develop in the future. The success of the Tunisian transition, particularly in its economic and social dimensions, is likely to pre-empt the further growth of the salafist phenomenon, in so far as it feeds on the deficiencies of nascent institutions and on worsening living conditions. Conversely, the failure to address convincingly the country's profound socioeconomic challenges is likely to embolden those salafists who have remained outside the political system and offer a radical alternative to the liberal democracy that is being built.

Paradoxically, the party that has the most to gain or lose, depending on how the transition will develop, is Ennahda. The party's decision to participate in the elections and to recognize the Tunisian institutional system was expected, given its ideological commitment to democratic procedures. The subsequent formation of a transitional coalition government with two leftist parties was also to be expected, given their previous history of cooperation while in exile. Finally, the condemnation of the violent salafi demonstrations on more than one occasion and the choice not to make sharia a source of legislation in the new constitution ${ }^{39}$ were also expected, given the conflict this might have generated. All of this alienated a number of Islamists, including some within the party itself. It is, therefore, not a surprise that the emergence and proliferation of salafi movements represent a significant challenge.

These manifestations of salafi Islamism reveal that Ennahda is not the only catalyst of consensus based on Islam. The party must deal with other actors who have their sources of legitimacy in Islamic principles and tend to question the very legitimacy of Ennahda on the basis of these values. Ennahda has attempted to defuse the salafists' challenge by sponsoring their entrance into the institutional system. They have been partially successful, but they have so far been unable to bring the more radical and popular groups into the institutional game, leaving themselves exposed in case of a failure to deliver on the promise of socioeconomic renewal..$^{40}$ In this framework, the political and reformist salafi parties that have been permitted to compete in the 2013 elections will have to choose whether to represent the antigovernment and social salafi movements and obtain their consensus, or to ally with Ennahda in an attempt to further isolate the jihadist fringes.

The final point has to do with the challenge that salafi movements present for Tunisian society as a whole, and in particular for secular sectors, which refer to them as a cancer that might threaten the process of democratization. Recent events, including demonstrations in support of sharia as a source of legislation, and attacks on some symbols of the supposed deviance of the country, have brought this phenomenon to the forefront of the political debate, both inside and outside Tunisia. While the significance of such events should not be underestimated, it should also be recog- 
nized that they have been paradoxically useful for strengthening the democratic and liberal resolve of those who are opposed to the salafist vision of society. Large parts of secular society were accustomed to demanding and obtaining protection from Ben Ali, supposedly a defender of secular modernization, against what they saw as religious bigotry directed against them and their lifestyles. ${ }^{41}$ Today, they are having to take responsibility for organizing and promoting their future in Tunisia against regressive ideologies. Counterdemonstrations, shows of support for those victimized by salafists, and petitions against regressive legislation demonstrate the vitality of Tunisian society and its attachments to the newfound freedoms that reinforce the validity of the democratic path.

Tunisian salafism is unlikely to derail the Tunisian transition, but closer attention should be paid to the phenomenon. It plays a significant role at the social level and could become a crucial political force in the future, if the governing coalition after the 2013 elections is unable to address the causes of discontent that led to the removal of Ben Ali.

\footnotetext{
${ }^{1}$ After the 2011 elections, the Islamist party Ennahda formed a coalitional government with Ettakatol and Congress for the Republic (CPR) — the first being social-democratic and the latter leftist-secularist.

${ }^{2}$ Alfred Stepan, “Tunisia's Transition and the Twin Tolerations," Journal of Democracy 23, no. 2 (2012): 89-103.

${ }^{3}$ Shadi Hamid, "The Rise of the Islamists," Foreign Affairs 90, no. 3 (2011): 39-47.

${ }^{4}$ For a discussion on the moderation of Islamist parties, see Jillian Schwedler, "Can Islamists Become Moderates? Re-thinking the Inclusion-Moderation Hypothesis," World Politics 63, no. 2 (2011): 347-376.

5 "Tunisie. Le cancer salafiste," La Jeune Afrique 52, no. 2683 (2012).

${ }^{6}$ In an interesting aside, Ali Hurrath had begun his salafist activism in the neighborhood of Ettadhem in Tunis, today a salafi stronghold.

${ }^{7}$ Interview with authors, Tunis, October 2012.

${ }^{8}$ See Laryssa Chomiak, "The Making of a Revolution in Tunisia," Middle East Law and Governance 3, no. 1 (2011): 68-83; and Laryssa Chomiak and John Entelis, "The Making of North Africa's Intifadas," Middle East Report, no. 259 (2011): 8-15.

${ }^{9}$ Francesco Cavatorta and Rikke Hostrup Haugbølle, "The End of Authoritarian Rule and the Mythology of Tunisia under Ben Ali," Mediterranean Politics 17, no. 2 (2012): 125-138.

${ }^{10}$ Ahmed An-Nahdif, "Salafism and Its Derivations: From Hanbalism to Wahhabism via Jihad," January 25 , 2012, http://www.ahewar.org/debat/show.art.asp?aid=308142 (in Arabic).

11 "Tarek Maaroufi: Tunisia’s Most Notorious Jihadist, Returns Home," Tunisia Live, April 1, 2012.

${ }^{12}$ Quintan Wiktorowicz, "Anatomy of the Salafi Movement," Studies in Conflict and Terrorism 29, no. 3 (2006): 207-239.

${ }^{13}$ Ibid., 225.

${ }^{14}$ Samir Amghar, Le salafisme d'aujourd'hui. Mouvements sectaires en Occident (Michalon, 2011).

${ }^{15}$ Available at http://thewasat.wordpress.com/2012/01/26/an-update-to-hegghammers-preference-basedanalysis-of-islamism/.

${ }^{16}$ Laurent Bonnefoy, Salafism in Yemen. Transnationalism and Religious Identity (Hurst and Company, 2011).

${ }^{17}$ Douija Mamelouk, "Article 28 of the Tunisian Constitution: A Problem among Many Others," September 6, 2012, http://www.jadaliyya.com/pages/index/7233/article-28-of-the-tunisian-constitution_a-problem-.

${ }^{18}$ Interview with authors, Tunis, October 2012.

${ }^{19}$ Jarret Brachman, Global Jihadism. Theory and Practice (Routledge, 2008), 34-35.

${ }^{20}$ The program is available at https://www.facebook.com/photo.php?fbid=386989028010382\&set=a.3609780 77278144.79259.360973397278612\&type=1. (in Arabic).
} 
21 “Tunisie. Le parti salafiste Jibhat Al-Islah déclare la guerre à la laïcité,” Kapitalis, July 9, 2012.

22 "Tunisia: Salafite Party Calls for Polygamy and Halt to Adoptions," Adnkronos International, May 23, 2012.

${ }^{23}$ See Stephen J. King, Liberalization against Democracy. The Local Politics of Economic Reform in Tunisia (Indiana University Press, 2003), 29.

24 "Rached Ghannouchi: Le salafisme tel qu'on le voit en Tunisie est un projet de guerre civile," Business News, March 28, 2012.

${ }^{25}$ For a recent study, see Noman Hanif, "Hizbut Tahrir: Islam's Ideological Vanguard,” British Journal of Middle Eastern Studies 39, no. 2 (2012): 201-225.

${ }^{26}$ Aaron Y. Zelin, "Jihadi Soft Power in Tunisia: Ansar al-Shariah's Convoy Provides Aid to the Town of Haydrah in West Central Tunisia," al-Wasat, the Muslim World, Radicalization, Terrorism, and Islamist Ideology, February 21, 2012.

${ }^{27}$ This information came from authors' interview with Hassan Briek in September 2012 in Jasminette shortly before his arrest for the attacks on the U.S. embassy. Hassan Briek was very reluctant to divulge more information about the internal structure of the group.

${ }^{28}$ Ibid.,43.

${ }^{29}$ Zelin, "Jihadi Soft Power in Tunisia."

${ }^{30}$ The page is available at http://www.facebook.com/Molta9a.Ansar.Alchari3a.

${ }^{31}$ In October 2011, just a few days before the elections for the Constituent Assembly, a group of Islamists attacked the headquarters of the television channel Nessma, following the broadcast of the French animated film "Persepolis," considered offensive to the Islamic religion. At the same time, a group of salafi students occupied by a sit-in the Faculty of Arts of Manouba University in Tunis, demanding that students who wanted to wear the niqab could do so, that a prayer room would be built and the separation of sexes within the classrooms enforced. They shouted the slogan, "my niqab is my freedom." The demonstrations have also assumed a violent character. A professor was almost held hostage in his office, which was ransacked. In March 2012, a large peaceful rally took place in the streets of Tunis in favor of the adoption of sharia in the new Tunisian constitution. On that occasion, one of the symbols of the capital, the clock tower in Avenue Bourguiba, was covered with the flag of jihadi movements. Other violent incidents occurred in Sidi Bouzid — the city of origin of Shaykh Khatib al-Idrissi — with an attack on some shops selling alcohol, and in the Tunis suburb of La Marsa, where salafis attacked a contemporary art exhibition, destroying some works. These episodes have a profound symbolic value. The secular part of society saw them as an attack against their vision of Tunisia, and salafists argued that such events have been overemphasized.

${ }^{32} \mathrm{http}: / /$ al-qayrawan.blogspot.it/2011/05/blog-post_14.html (in Arabic).

${ }^{33} \mathrm{http}: / /$ www.facebook.com/media/set/?set=a.296299897070305.79557.211220622244900\&type=3 (in Arabic).

${ }^{34}$ On May 16, 2003, a series of suicide bombings struck Casablanca, causing 45 deaths and resulting in the heaviest terrorist attack in the history of Morocco. Al-Hadushi was sentenced to 30 years in prison on the charge of "moral" responsibility for the attack. See Selma Belaala, "Jihad misère et au Maroc," Le Monde diplomatique, November 2004. In February 2011, he was released after an amnesty, sought by King Muhammad VI.

35 "Radical Mosques Invite Young Tunisians to Jihad in Syria," Al-Arabiyya, May 18, 2012.

36 “Tunisie : un super ministère de la police religieuse?" Investir en Tunisie, July 27, 2012

37 “Adel El Almi, fondateur de la police religieuse, met en garde les non jeûneurs," Webdo.tn, July 17, 2012.

38 "Coupole d'El Menzah — Associations religieuses : 'Nous lutterons contre tout ce qui est contraire à la Chariâa," Business News, March 20, 2012.

${ }^{39}$ In March 2012, during the work on the new constitution, Rachid Ghannouchi announced that the party would not support making any reference to sharia as a source of law in the new constitutional text.

${ }^{40}$ Alice Fordham, "Tunisia Heartland Rues Unfulfilled Promise," The National, September 4, 2012.

${ }^{41}$ Nadia Marzouki, "Four Keys to Understand Tunisian Politics after the Elections," Focus Article 62, November 2011: 1-4. 